\title{
Household Incomes and Bank Residential Mortgage in Russia
}

\author{
Olga Miroshnichenko ${ }^{1, *}$, Anna Tarasova ${ }^{2}$, and Valeriy Gamukin ${ }^{1}$ \\ ${ }^{1}$ University of Tyumen, 625003 Tyumen, Russia \\ ${ }^{2}$ Ural Federal University, 620002 Ekaterinburg, Russia
}

\begin{abstract}
The influence of the incomes of the population subject to changes on bank mortgage lending was investigated using the methods of correlation and regression analysis. Three approaches to income volatility as an indicator of their volatility have been implemented: variability within certain time periods through an assessment of the coefficients of variation during the year, between periods through an assessment of the average annual income growth rates, and the variability of the distribution between income recipients through inequality indicators. According to the research results, indicators of bank residential mortgage are more strongly associated with variations in nominal income than in real one; the low level of overdue mortgage debt in the Russian banking sector is determined by a qualitative assessment of borrowers' capabilities in accordance with their income; an increase in income volatility is accompanied by a decrease in the share of overdue mortgage debt. The stability of the population's income contributes to an increase in the number and total volume of bank residential mortgage. As a result of econometric modeling, the maximum significant effect of the unemployment rate on the share of overdue mortgage debt has been established.
\end{abstract}

\section{Introduction}

Key parameters of a loan transaction are determined by indicators characterizing the borrower's income. The amount of income can differ significantly at different time intervals within the crediting period, for example, between different months of the same year, between different years. Changes in income are possible both upward and downward. Payments on bank residential mortgage of a certain size must be made on time, and do not depend on the volatility, or variability of income. The volatility of income of mortgage borrowers is the most important risk factor for a residential mortgage.

The aim of this work is to study the impact of incomes of the population subject to changes on bank residential mortgage in Russia.

The study of banking risks of residential mortgage is widely developing along the way of assessing potential financial losses during the implementation of risk events, identifying significant risk factors [1-6].

\footnotetext{
*Corresponding author: o.s.miroshnichenko@utmn.ru
} 
In the EU countries, the borrower's income is positively and statistically significantly associated with the expansion of mortgage lending and the emergence of overdue payments on residential mortgage [7]. In the United States and the Netherlands, the borrower's high income determines the desire to repay debt on residential mortgage ahead of schedule [8, 9]. A negative correlation between the incomes of borrowers and arrears on residential mortgage was noted in the USA [10], Italy [11], Ireland [12], the Netherlands [13]. The determinants of overdue debt on residential mortgage in the EU are not so much income as its volatility: the higher the volatility, the higher the likelihood of delinquency on residential mortgage [7].

To assess the influence of borrowers' income on the occurrence of overdue debt on residential mortgage, scientific literature uses such indicators as the size of the loan $[14,15$, $11,7,16,17,18]$; loan term $[19,14,15,12]$; interest rate on residential mortgage $[19,14$, $12,8,11,7,20]$; unemployment rate / employment rate $[14,7,12,16,8,17,21]$; Gini coefficient $[7,16]$. At the same time, studies devoted to assessing the impact of the volatility of incomes of the Russian population on banking residetial mortgage are not fully represented in the scientific literature.

\section{Materials and methods}

The study is based on a statistical background formed from the indicators of the official statistics for the period of 2008-2018: indicators of residential mortgage in rubles and in foreign currency [22], the unemployment rate (for 2008-2009 is presented by year, and for 2010-2018 - quarterly), the decile coefficient of funds and Gini coefficient, the consumer price index (CPI), the average resident population per year, the average per capita money income of the Russian population [23, 24]. When constructing aggregated time series by quarters, by years, the CPI was recalculated for the corresponding periods according to the Rosstat methodology. When working with time series of the indicators, the method of correlation of moments of products (Pearson's correlation coefficient), a multiple linear regression model with a stepwise selection of predictors were used. The probability $\mathrm{F}$ was taken as a selection criterion: for inclusion $<=0.05$ and for exclusion $>=0.1$.

When studying the variability of the population's income and its impact on the development of banking residential mortgage, it was taken into account that in the relevant studies of foreign authors in the context of the variability of the population's income, the concept of "volatility" of income is used. Considering that there is no single point of view on the empirical interpretation of income volatility and a single formula for its calculation, this study uses three approaches to considering income volatility as an indicator of their volatility: volatility within certain time periods [see, eg, 7], variability between these periods [see, eg, 12, 15], and variability of distribution among income recipients [see, eg, 7, $11,16]$. The use of alternative measures of income variability determines the novelty of the author's approach and contributes to complementing the existing literature.

\section{Results and discussion}

In the first approach to assessing the relationship between the indicators of banking residential mortgage and indicators of household income, the coefficients of variation are used as standardized measures of the spread of average monthly per capita income during the year (volatility as the variability of income within individual intervals of the analyzed period). The coefficients of variation calculated for both nominal and real (taking into account the CPI) average monthly per capita income strongly correlate with each other ( 0.902 with an error of less than $0.1 \%$ ), demonstrating similar dynamics. The volatility of the average per capita income of the Russian population during the year is largely 
determined by the difference between December last year and January this year, which is associated with the peculiarities of wage payments in Russia. To exclude the distortion of the results of identifying statistically significant relationships between the population's income and the residential mortgage indicators, the coefficients of intra-annual variation were calculated, from which the extremes of January and December were excluded. As a result, it was found that the increase in the volatility of household income during the year is accompanied by a decrease in the volume of urgent and overdue debt. A different situation is typical for a bank residential mortgage in foreign currency. The increase in the balance of debt on foreign currency residential mortgage is associated with the depreciation of the ruble (against the background of the volatility of nominal income), which increases the risks of the banking sector, further leading to a decrease in the number and volume of newly issued residential mortgage in foreign currency.

Taking into account that a prolonged effect of the influence of the intra-annual variation of the average monthly cash income of the population on the indicators of residential mortgage is possible, a correlation analysis with shifted time series has been carried out. Based on its results, the following has been established:

1) banking sector reacts to changes in the monetary income of the population rather quickly, most of the identified relationships appear already in the same period; 2) indicators of banking residential mortgage are more strongly associated with variations in nominal income than real income (calculated taking into account the CPI); 3) an increase in the variability of household incomes within a year, in the next period is accompanied by an increase in the weighted average interest rate on loans (there is a strong direct relationship: the Pearson correlation coefficient is 0.877 with a maximum significance level of 0.001 ), as well as a decrease in the number and volume of residential mortgage issued in rubles (the relationship is moderate inverse, -0.632 and -0.646 , respectively). Conversely, with a decrease in the volatility of household incomes within a year, the number and volume of provided residential mortgage increases.

The second approach to assessing the impact of population income volatility on the development of banking residential mortgage is possible through an assessment of the average annual growth rates and income growth (volatility as a variability of dynamics, Table 1).

Table 1. Correlation between the growth rate of the average monthly per capita income of the population of Russia and the debt on bank residential mortgage

\begin{tabular}{|c|c|c|c|c|}
\hline & \multicolumn{2}{|c|}{$\begin{array}{l}\text { Growth rate of the nominal average } \\
\text { monthly per capita income of the } \\
\text { population }\end{array}$} & \multicolumn{2}{|c|}{$\begin{array}{l}\text { Growth rate of the actual average } \\
\text { monthly per capita income of the } \\
\text { population }\end{array}$} \\
\hline & Current year & Last year & Current year & Last year \\
\hline $\begin{array}{l}\text { Total residential mortgage } \\
\text { issued in rubles }\end{array}$ & $\begin{array}{c}-0.739 * \\
(\text { Sig. }=0.015)\end{array}$ & $\begin{array}{c}-0.760 * \\
(\text { Sig. }=0.017)\end{array}$ & $\begin{array}{c}-0.519 \\
\text { (Sig. }=0.124)\end{array}$ & $\begin{array}{c}-0.376 \\
\text { (Sig. }=0.318)\end{array}$ \\
\hline $\begin{array}{l}\text { Total residential mortgage } \\
\text { issued in foreign currency }\end{array}$ & $\begin{array}{c}0.763^{*} \\
(\text { Sig. }=0.010)\end{array}$ & $\begin{array}{c}0.747^{*} \\
(\text { Sig. }=0.021)\end{array}$ & $\begin{array}{c}\mathbf{0 , 7 6 9 * *} \\
(\text { Sig. }=0.009)\end{array}$ & $\begin{array}{c}0.764^{*} \\
(\text { Sig.=0.017) }\end{array}$ \\
\hline $\begin{array}{l}\text { Volume of loans provided } \\
\text { in rubles }\end{array}$ & $\begin{array}{c}-0.740 * \\
(\text { Sig. }=0.014)\end{array}$ & $\begin{array}{c}-0.785^{*} \\
(\text { Sig. }=0.012)\end{array}$ & $\begin{array}{c}-0.513 \\
(\text { Sig. }=0.130) \\
\end{array}$ & $\begin{array}{c}-0.402 \\
\text { (Sig. }=0.284) \\
\end{array}$ \\
\hline $\begin{array}{l}\text { Volume of loans provided } \\
\text { in foreign currency }\end{array}$ & $\begin{array}{c}\mathbf{0 . 7 5 8}^{*} \\
(\text { Sig. }=0.011)\end{array}$ & $\begin{array}{c}0.805^{* *} \\
(\text { Sig. }=0.009)\end{array}$ & $\begin{array}{c}0.687 * \\
(\text { Sig. }=0.028)\end{array}$ & $\begin{array}{c}0.859 * * \\
(\text { Sig. }=0.003)\end{array}$ \\
\hline Loan debt in rubles & $\begin{array}{c}-0.844 * * \\
(\text { Sig. }=0.002)\end{array}$ & $\begin{array}{c}-0.857 * * \\
(\text { Sig. }=0.003)\end{array}$ & $\begin{array}{c}-0.677 * \\
(\text { Sig. }=0.032)\end{array}$ & $\begin{array}{c}-0.704 * \\
(\text { Sig.=0.034) } \\
\end{array}$ \\
\hline $\begin{array}{l}\text { Loan debt in foreign } \\
\text { currency }\end{array}$ & $\begin{array}{c}0.839 * * \\
(\text { Sig. }=0,002)\end{array}$ & $\begin{array}{c}0.859 * * \\
(\text { Sig. }=0,003)\end{array}$ & $\begin{array}{c}0.461 \\
(\text { Sig. }=0.180)\end{array}$ & $\begin{array}{c}0.642 \\
(\mathrm{Sig} .=0.062)\end{array}$ \\
\hline Loan arrears in rubles & $\begin{array}{c}-0.873 * * \\
(\text { Sig. }=0.001) \\
\end{array}$ & $\begin{array}{c}-0.901 * * \\
(\text { Sig. }=0.001)\end{array}$ & $\begin{array}{c}-0.598 \\
(\text { Sig. }=0.068) \\
\end{array}$ & $\begin{array}{c}-\mathbf{0 , 8 0 6 * *} \\
(\text { Sig. }=0.010)\end{array}$ \\
\hline $\begin{array}{l}\text { Share of overdue debt in total } \\
\text { debt on residential mortgage } \\
\text { issued in foreign currency, } \%\end{array}$ & $\begin{array}{c}-0.914 * * \\
(\text { Sig. }=0.000)\end{array}$ & $\begin{array}{c}-0.853 * * \\
(\text { Sig. }=0.003)\end{array}$ & $\begin{array}{c}-0.608 \\
(\mathrm{Sig} .=0.062)\end{array}$ & $\begin{array}{c}-0,830 * * \\
(\text { Sig. }=0.006)\end{array}$ \\
\hline
\end{tabular}


${ }^{*}$ correlation is significant at 0.05 level (two-sided)

** correlation is significant at 0.01 level (two-sided)

The relationship between nominal incomes and indicators of bank residential mortgage is stronger than real incomes. For residential mortgage in rubles, with an increase in income growth rates, the increase is directed to cover both total debt and overdue debt, the share of overdue debt does not change significantly. The increase in income growth rates is not a factor in the increase in the issuance of residential mortgage. The growth rate of average monthly per capita income has a prolonged effect on the debt, and in the next period the influence is increasing. The volume of issuance of residential mortgage in rubles is determined by the size, but not by the dynamics of growth in the nominal income of the population. For residential mortgage in foreign currency, with an increase in income volatility, the volume of issuance and the balance of debt increase; the amount of overdue does not change significantly, the share of overdue is reduced. Residential mortgage debt in foreign currency is associated with the dynamics of nominal income, which is caused by inflationary processes, changes in the exchange rate, and, as a result, an increase in the balance of residential mortgage debt in foreign currency.

The third approach to assessing the impact of the variability of the population's income on the development of banking residential mortgage involves considering the variability of income between different groups of income recipients through the indicators of inequality in society. As empirical indicators, Gini coefficient, the decile coefficient of funds and the unemployment rate indicator are used, which determines the spread of income in society, characterizes the variability of income levels, and can determine the level of risks of a banking residential mortgage.

Inequality indicators appear to be strongly associated with residential mortgage in rubles (Table 2). The presence of statistically significant links, both with the issuance of such loans and with the debt on them, has been noted. There are no such connections with residential mortgage in foreign currency, there is a connection with the weighted average term and the lending rate for foreign currency loans.

Table 2. Correlation between indicators of income inequality in Russia and bank residential mortgage in rubles

\begin{tabular}{|c|c|c|c|c|c|c|}
\hline & \multicolumn{2}{|c|}{$\begin{array}{l}\text { Decile coefficient of } \\
\text { funds }\end{array}$} & \multicolumn{2}{|c|}{ Gini coefficient } & \multicolumn{2}{|c|}{ Unemployment rate } \\
\hline & $\begin{array}{c}\text { Pearson } \\
\text { Correlation } \\
\end{array}$ & Value & $\begin{array}{c}\text { Pearson } \\
\text { Correlation } \\
\end{array}$ & Value & $\begin{array}{c}\text { Pearson } \\
\text { Correlation }\end{array}$ & Value \\
\hline $\begin{array}{l}\text { Total residential mortgage provided } \\
\text { in rubles }\end{array}$ & $-0.803^{* *}$ & 0.003 & $-0.792^{* *}$ & 0.004 & $-0.884^{* *}$ & 0.000 \\
\hline $\begin{array}{l}\text { Volume of residential mortgage } \\
\text { provided in rubles }\end{array}$ & $-0.800^{* * *}$ & 0.003 & $-0.796 * *$ & 0.003 & $-0.840^{* *}$ & 0.001 \\
\hline Total loan arrears in rubles & $-0.933^{* *}$ & 0.000 & $-0.928^{* *}$ & 0.000 & $-0.769^{* *}$ & 0.006 \\
\hline Loan arrears in rubles & $-0.922^{* *}$ & 0.000 & $-0.920^{* *}$ & 0.000 & $-0.614 *$ & 0.044 \\
\hline $\begin{array}{l}\text { Share of overdue debt in total debt on } \\
\text { residential mortgage issued in rubles, } \\
\%\end{array}$ & 0.486 & 0.130 & 0.462 & 0.153 & $0.812^{* *}$ & 0.002 \\
\hline
\end{tabular}

With the growth of inequality in society, the volume of newly issued residentiaal mortgage decreases, since for high-income strata credit is less relevant, and for low-income groups of the population it becomes less available. Income inequality in society has a prolonged impact on banking residential mortgage in Russia. With a shift by one period, the above-mentioned connections are preserved and even strengthened. It is the inequality in the income of the population that is the main factor determining the scale of the banking residential mortgage in Russia. 
The unemployment rate in the country has the best predictive ability to characterize the growth rate of overdue residential mortgage debt in rubles, as well as the share of overdue debt in the total, is the unemployment rate in the country (see Table 2). A linear regression model has been built, in which the target variable is the share of overdue debt in the total residential mortgage debt in rubles, the independent variables (influencing factors) are the population growth rate, the growth rate of nominal and real per capita income, CPI, variation coefficients of nominal and real income, and indicators of inequality. As a result of stepwise selection, only one variable is included in the model - the unemployment rate. All other factors are excluded as insignificant ones (coefficients of the linear regression equation: non-standardized coefficients $\mathrm{B}=0.233$, standard error 0.024 ), standardized coefficients (Beta 0.957), $\mathrm{t}=9.896$ ). Adjusted coefficient of determination $\left(\mathrm{R}^{2}\right)=0.906$; Fisher statistic probability $(\mathrm{F}$-statistic $)=0.000$. The impact of unemployment on the share of arrears is maximally significant, each percentage of unemployment increases the share of overdue debts by $0.233 \%$. The decrease in the nominal income of the population determines the decrease in the issuance of bank residential mortgage, and the corresponding debt, including overdue debt, but does not significantly affect the share of overdue.

\section{Conclusion}

Bank residential mortgage indicators are more strongly associated with variations in nominal income than real income. In the context of volatility in the incomes of Russian households, increasing incomes are used to pay off bank residential mortgage debt. Bank residential mortgage is associated not so much with the average monthly income of the population, the amplitude or dynamics of changes in this income, but with how this income is distributed in society. The main factor that determines the level of overdue on bank residential mortgage in Russia is the unemployment rate.

\section{Acknowledgements}

The reported study was funded by RFBR No. 19-010-00801.

\section{References}

1. N.A. L'vova, N.V. Pokrovskaya, V.V. Ivanov, Economic and social changes: facts, trends, forecast, 10(4), 196 (2017)

2. N.S. Voronova, O.S. Miroshnichenko, Economic and Social Changes: Facts, Trends, Forecast, 11(4), 144 (2018)

3. O. S. Miroshnichenko, A. N. Tarasova, Economy of Region, 14(1), 303 (2018)

4. V.V. Manuylenko, M.A. Loktionova, O. B. Bigday, V. N. Glaz, E. A. Drannikova, Journal of Applied Economic Sciences, XIII(3), 637 (2018)

5. V.V. Manuylenko, D. Ryzin, M.N. Konyagina, N.V. Lipchiu, L.A. Setchenkova, TEM Journal: Technology, Education, Management, Informatics. 2020. Vol. 9. No. 3. P. 1116-1125.

6. V.V. Ivanov, N.A. Lvova, N.V. Pokrovskaia, R.K. Nurmukhametov, S.V. Naumenkova, Proceedings of the 33rd International Business Information Management Association Conference, IBIMA 2019: Education Excellence and Innovation Management through Vision 2020.33, Education Excellence and Innovation Management through Vision 2020, 2747 (2019)

7. L. Diaz-Serrano, Journal of Housing Economics, 14(3), 153 (2005) 
8. C. L. Foote, P. S. Willen, Annual Review of Financial Economics, 10, 59 (2018)

9. S. P.T. Groot, A. M. Lejour, Journal of Housing Economics, 41, 237 (2018)

10. J. C. Hatchondo, L. Martinez, J. M. Sánchez, Journal of Monetary Economics, 76, 173 (2015)

11. S. Mocetti, E. Viviano, Journal of Banking \& Finance, 75, 53 (2017)

12. R. Kelly, F. McCann, Journal of Banking \& Finance, 72, 15 (2016)

13. H. Fout, G. Li, M. Palim, Y. Pan, Credit risk of low income mortgages, Regional Science and Urban Economics (2018)

14. D. H. Xuan, D. Rösch, H. Scheule, European Journal of Operational Research, 270(1), 246 (2018)

15. F. Andersson, T. Mayock, Journal of Banking \& Finance, 46, 266 (2014)

16. M. U. Özmen, M. K. Kalafatcilar, E. Yilmaz, Central Bank Review, 19(2), 45 (2019)

17. A.K. Moiseev, M.V. Cherkovets, Problems of Forecasting, 5, 112 (2014)

18. V. Gamukin, Economy of Region, 16(3), 1003 (2020)

19. S. Chen, Z. Guo, X. Zhao, European Journal of Operational Research, 5 August (2020)

20. E.V. Kuz'mina, A.A. Yanin, Finance: Theory and Practice, 22(6), 106 (2018)

21. J. Kaźmierczyk, A. Chinalska, Entrepreneurship and Sustainability Issues, 6(2), 782 (2018)

22. Bank of Russia, http://old.cbr.ru/statistics/pdko/Mortgage/

23. Unified interdepartmental information and statistical system, https://fedstat.ru/

24. Federal State Statistics Service, https://www.gks.ru/ 